\title{
Fertility and milk production in Dutch Friesian cattle
}

\author{
J. H. M. Metz and R. D. Politiek
}

Department of Animal Husbandry, Agricultural University, Wageningen, the Netherlands

Received 1 September 1969

\section{Summary}

To analyse the relation between fertility and milk yield, production data from the first lactation was used. Fertility data were compiled during the first and second breeding period for both artificial insemination (AI) and natural service (NS).

In 545 herds, 1943 heifers were studied in West Friesland, a district in the Dutch province of North Holland.

1. Milk yield data could be corrected for herd level (relative milk production) because there was a strong correlation $(\mathrm{r}=+0.53)$ between the average production level of the herd in one year and the average milk production per day of the individual heifers in the next year (Table 1).

2. For the first and second breeding period the number of AI services (1.39 and 1.44) were somewhat higher than NS (1.23 and 1.28). Therefore it was necessary to do calculations within breeding methods (Table 2).

3. No significant relations were found between the absolute average milk yield per day and the characters of fertility in the first and second breeding period (Table 5).

4. There was no significant relation of relative milk production with fertility data in the second breeding period in comparisons within herds on high, medium and low production level (Table 6).

5. There was no evidence for any correlation between herd level of production and fertility data (Table 7).

6. Herd environment was responsible for about $40 \%$ of the variance in milk production of individual cows, but was still significant, though of less importance for age at first calving $(16 \%)$, calving-service period $(12 \%)$ and calving-conception interval $(6 \%)$ (Table 8).

7. The estimated $h^{2}$ (heritability) for milk production during lactation was 0.31 . An $\mathrm{h}^{2}$ of 0.08 was calculated both for the number of inseminations necessary for first and second pregnancy and for age at first calving (Table 9).

8. No significant additive genetic correlations were found between milk production and fertility characters.

\section{Introduction}

The relationship between the level of milk production and fertility in dairy cattle has been studied by, for instance Gaines (1927), Boyd et al. (1954), Currie (1956), Touchberry et al. (1959), Smith and Legates (1962), Lampo et al. (1963), Damm (1965), Dannenberg (1967) and Weseloh (1968). Most of these authors did not find evidence 
suggesting any relationship. On the contrary some authors (Lampo et al., 1963 ; Damm, 1965; Weseloh, 1968) found that at least above a certain production level a further rise in the amount of milk was related with less fertility. This negative relationship was explained by lactation stress in high-yielding cows.

The aim of the present study is to analyse the relationship between milk production and fertility characteristics under Dutch farming conditions, especially in a district with a high production level. This enabled us to pay special attention to possible effects of lactation stress.

\section{Material and method}

At eight milk recording associations in West Friesland, in the province of North Holland, data were collected of 1943 Dutch Friesian heifers from 545 herds. The recorded data concern only the main calving season, namely February, March and April from 1965 , in order to avoid seasonal effects on milk production and fertility. The heifers had completed their first lactation and had obviously become pregnant during that lactation. All of them had at least one herd mate in the material.

For the herds the average milk production per day in 1964-1965 was taken as a measure of the production level of the herd. This record was corrected by the method of linear regression for differences in the average age at calving.

Thus two criteria for the individual milk production could be used:

a. The average production per day, calculated from the total milk yield during the 305-days lactation, and

b. The corrected production per day, which is the difference between the production in a) and the herd level.

In this way both absolute milk production and relative milk production could be related to fertility data.

The following fertility data were collected for the first (no lactation stress) and the second pregnancy (where lactation stress may occur):

number of services to effect first pregnancy;

number of services necessary for the second pregnancy (during lactation);

age at first calving;

interval between calving and first service;

interval between calving and conception.

They were separated according to the breeding method, namely artificial insemination (AI) and natural service (NS). Some incomplete data concerning the first conception will be found in the tables. The calving-service interval was estimated from the calving-conception interval by reducing it by 21 days for every repeated service.

The statistical methods used were primarily. based on the frequency distribution of the characters (partly parameter-free). The genetic parameters were calculated with the use of parametric methods, irrespective of the normality of the distribution.

\section{Results of the investigations}

Analyses of some environmental effects

Relationship between herd level and average daily production

On account of the strong correlation $(r=+0.53)$ and regression $(b=+0.43)$ between the average production level of the herd in 1964-1965 and the average milk 
Table 1 Relation between herd level and individual average production per day

\begin{tabular}{lcc}
\hline & Average & $\begin{array}{c}\text { Standard } \\
\text { deviation }\end{array}$ \\
Herd level in $\mathrm{kg}(\mathrm{y})$ & 15.38 & 1.61 \\
Average production per day in $\mathrm{kg}(\mathrm{x})$ & 12.49 & 2.00 \\
\hline $\mathrm{r}=+0.53$; d.f. $=1806 ; \mathrm{P}<0.005 ;$ & $\mathrm{b}_{\mathrm{yx}}=+0.43$. &
\end{tabular}

production per day of the individual heifers in the next year (Table 1) it was safe to accept herd level as a good measure for the herd environment and production conditions of the heifers. It also enabled correction of the individual milk yield for herd level (relative production).

Difference in breeding results and milk production between the AI and NS group

As appears from Table 2 there was a significant difference in 0.16 units between the average number of services in AI and NS for both conceptions in favour of NS.

The average production of about $3800 \mathrm{~kg}$ milk in the first lactation ( 305 days) for heifers calving when they are 2 years old is a high level for Dutch conditions. The group of NS heifers had a small, but significantly higher production than the AI animals. Apparently this cannot be explained by the breeding method, but by the intensity of farming of more specialized breeders in the NS group.

To prevent disturbing effects of this factor and others associated with the method of breeding, further analysis of fertility and milk production was carried out within the AI and NS groups.

Table 2 Difference in breeding results and milk production between $A I$ and NS groups

\begin{tabular}{lcccccc}
\hline $\begin{array}{l}\text { Breeding } \\
\text { method }\end{array}$ & $\begin{array}{c}\text { Number } \\
\text { of } \\
\text { animals }\end{array}$ & $\begin{array}{c}\text { Number of } \\
\text { services } \\
\text { producing } \\
\text { first } \\
\text { pregnancy }\end{array}$ & $\begin{array}{c}\text { Average } \\
\text { production } \\
\text { per day } \\
(\mathrm{kg})\end{array}$ & $\begin{array}{c}\text { Number } \\
\text { of } \\
\text { animals }\end{array}$ & $\begin{array}{c}\text { Number of } \\
\text { services } \\
\text { producing } \\
\text { first } \\
\text { pregnancy }\end{array}$ & $\begin{array}{c}\text { Average } \\
\text { production } \\
\text { per day } \\
(\mathrm{kg})\end{array}$ \\
$\begin{array}{l}\text { AI } \\
\text { NS }\end{array}$ & 1215 & 1.39 & 12.41 & 1412 & 1.44 & 12.39 \\
$\begin{array}{l}\text { total } \\
\text { average }\end{array}$ & 1826 & 1.23 & 12.65 & 531 & 1.28 & 12.64 \\
$\begin{array}{l}\text { test } \\
\text { values }\end{array}$ & 1.33 & 12.49 & 1943 & 1.40 & 12.46 \\
\hline
\end{tabular}

* $\mathrm{P}<0.05 ; * * \mathrm{P}<0.005$.

Some relationships between the criterions of fertility

Number of services, age at first calving and calving-conception interval. For both the NS and the AI heifers a significant relationship was found between the number of services required to produce first pregnancy and the age at first calving and between 
Table 3 Relation between number of services and age at first calving as well as calving-conception interval in the AI heifers

\begin{tabular}{|c|c|c|c|c|}
\hline \multirow{2}{*}{$\begin{array}{l}\text { Number of } \\
\text { services }\end{array}$} & \multicolumn{2}{|c|}{ First conception } & \multicolumn{2}{|c|}{ Second conception } \\
\hline & $\begin{array}{c}\text { number of } \\
\text { animals }\end{array}$ & $\begin{array}{c}\text { age at first } \\
\text { calving in months }\end{array}$ & $\begin{array}{c}\text { number of } \\
\text { animals }\end{array}$ & $\begin{array}{l}\text { calving-conception } \\
\text { interval in days }\end{array}$ \\
\hline $\begin{array}{r}1 \\
2 \\
3 \\
24\end{array}$ & $\begin{array}{r}850 \\
278 \\
61 \\
26\end{array}$ & $\begin{array}{l}24.17 \\
24.85 \\
25.40 \\
26.30\end{array}$ & $\begin{array}{r}978 \\
310 \\
76 \\
48\end{array}$ & $\begin{array}{r}83 \\
109 \\
126 \\
159\end{array}$ \\
\hline $\begin{array}{l}\text { total } \\
\text { average }\end{array}$ & 1215 & 24.44 & 1412 & 94 \\
\hline $\begin{array}{l}\text { test } \\
\text { value }\end{array}$ & & $\mathrm{F}=55.77 * *$ & & $F=255.12 * *$ \\
\hline
\end{tabular}

** $\mathrm{P}<0.005$.

the corresponding second breeding results and the calving-conception interval. There was no essential difference between the two groups; therefore only the figure of the AI group will be shown (Table 3 ).

Age at first calving and calving-conception interval increased with the number of inseminations. The variation in the number of services caused $23 \%$ of the total variance of the age at first calving and $54 \%$ of the variance of the calving-conception interval. The rest of the variances of both parameters are surely partly caused by management factors, and probably partly by variation in reproductive functions. On the basis of this conclusion these parameters were used as separate criteria of fertility.

Age at first calving - calving-conception interval. In both the AI and NS group there was a significant relationship. With a longer calving-service interval, the age at first calving was earlier (Fig. 1). It seems, that this relationship was caused by the farmer, who tried to compensate a higher age at first calving by a shorter calving-service interval.

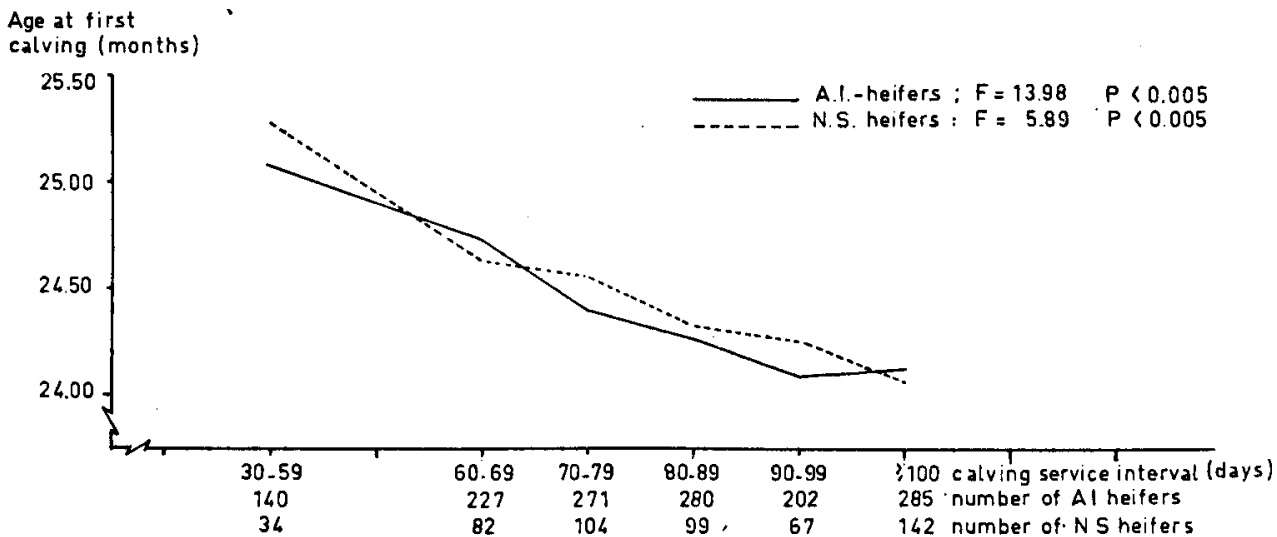

Fig. 1 Relation between age at first calving and calving-service interval. 


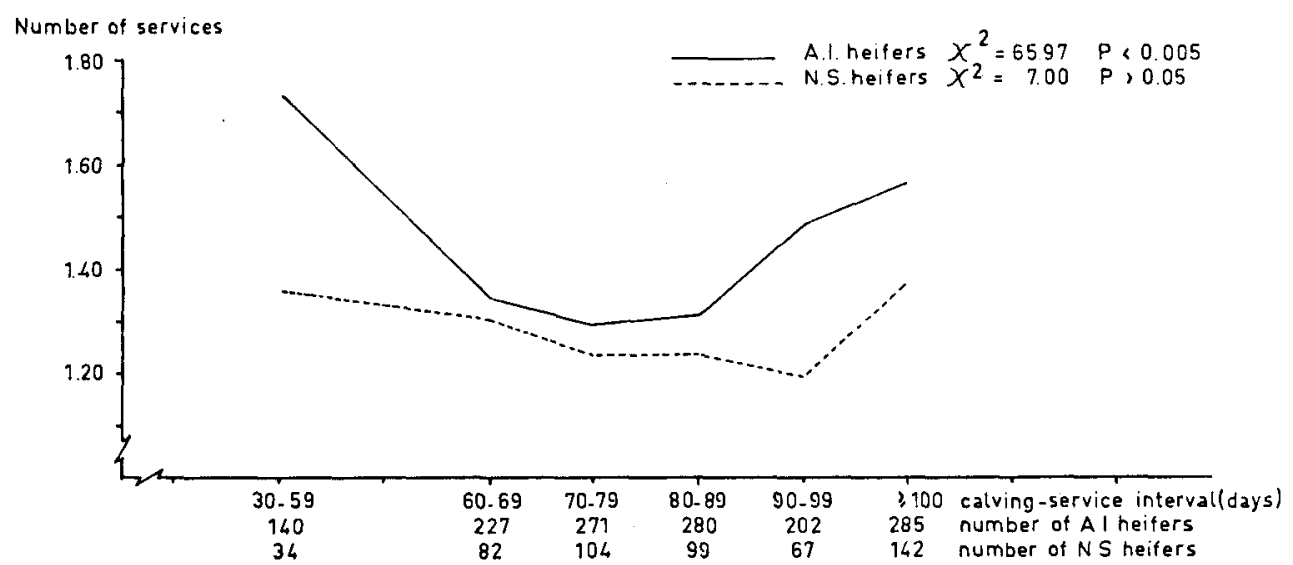

Fig. 2 Relation between calving-service interval and second breeding results.

In Fig. 1 the $7 \mathrm{AI}$ heifers (average age at first calving 24.6 months) and 3 NS heifers (average age at first calving 25.0 months) in the class of calving-service intervals shorter than 30 days are excluded. These short intervals are undoubtedly result from estimation errors of the interval. However, the test values were calculated for the whole group.

Calving-service interval and number of services during lactation. As shown in Fig. 2, there was in the AI group a significant relationship between the calving-service interval and the second breeding results. In the NS group there was no significant relationship although the curve showed the same trend as in the first group. Per class of calving-service interval, the number of animals was the same as in Fig. 1. Here too the test values were applied to the figures of the whole group. The excluded 7 AI and 3 NS heifers required on average 3.71 and 1.66 services, respectively.

The trend of the curves showed that, according to literature, early breeding (within two months after calving) had a depressing effect on breeding results (e.g. Boyd and Reed, 1961), and also late breeding (more than 3 months after calving). In the late breeding groups there surely have been animals with disturbed reproductive functions soon after calving, so that they could not be bred earlier. At any rate, late breeding was accompanied by depressed fertility.

If early and late breeding (in this case: conception) has a relatively negative and positive effect on milk production, respectively, as found by Smith and Legates (1962), only the length of the calving-service interval can cause a correlation between production and breeding results. We did not, however, find evidence for this conclusion, because analysis of variance gave no significant relationship between average production per day and calving-conception interval.

Number of services in first and second breeding period. Using the data of 1181 AI heifers we failed to find a significant relationship, although the figures in Table 4 suggest some positive relationship. The test value of the $\chi^{2}$-test on stochastic independence (de Jonge, 1964), applied on a $3 \times 3$ table with absolute figures, was 5.13 $(\mathrm{P}>0.10)$.

As a consequence for practical breeding it was demonstrated that in the case of a 
FERTILITY AND MILK PRODUCTION IN DUTCH FRIESIAN CATTLE

Table 4 Relation between number of services producing first and second pregnancy

Number of services

producing first pregnancy
Number of

animals
Distribution according to the second breeding results (\%)

\begin{tabular}{lrcccc} 
& & \multicolumn{4}{c}{ number of services } \\
\cline { 3 - 6 } & & 1 & 2 & 3 & $\geqslant 4$ \\
1 & 825 & 69.3 & 21.9 & 5.2 & 3.5 \\
2 & 271 & 67.9 & 22.1 & 6.6 & 3.3 \\
3 & 60 & 61.7 & 31.7 & 5.0 & 1.7 \\
4 & 25 & 64.0 & 32.0 & 4.0 & -
\end{tabular}

character such as fertility with a very low repeatability, selection based on first breeding results has practically no effect on the second breeding period.

For this investigation it would be useful to make calculations with the first and second breeding results separately, because the relationship with milk production might be very different.

\section{Relationship between average daily production and fertility}

For AI and NS material separately and for first breeding period (no lactation stress) and second breeding period (in which lactation stress is possible) the average milk production per day was divided into 10 sub-classes (from $<9$ to $\geqslant 17 \mathrm{~kg}$ per day). As shown in Table 5, no significant relationship was found, nor was there any, evidence for a relationship with milk production in analysing variance, with the number of services as sources of variance. These results are in agreement with conclusions of Gaines (1927), Boyd et al. (1954), Currie (1956), Touchberry et al. (1969), Smith and Legates (1962) and Dannenberg (1967), but differ from those of Damm (1965), Lampo et al. (1963) and Weseloh (1968). Damm found a negative relationship with the 120days milk production, so a higher production was associated with lower fertility. Corresponding results were found by Weseloh, who used the 100-days milk production.

For a daily production between 11.5 and $17.5 \mathrm{~kg}$ Lampo et al. (1963) found a positive relationship with the calving-conception interval. They could not conclude, however, whether this relation was caused by physiological mechanism or by systematical influence of management factors.

Relationship between corrected daily production and second breeding results

According to investigators as Dannenberg (1967), the heifers with a high production relative to the herd level should have less fertility during lactation. In this investigation this could not be confirmed. For AI and NS material separately, subdivided into three and two groups, respectively, by the herd production level, the relative milk production in 7 classes is given in Table 6. Within each class no evidence was found for a relation between milk production and the parameters of fertility. There was not any evidence either for the hypothesized phenomenon of lactation stress. It may be noted that Dannenberg did not find any relation between the absolute production and fertility, but when he used the relative production a higher yield was attended with less favourable breeding results. 
J. H. M. METZ AND R. D. POLITIEK

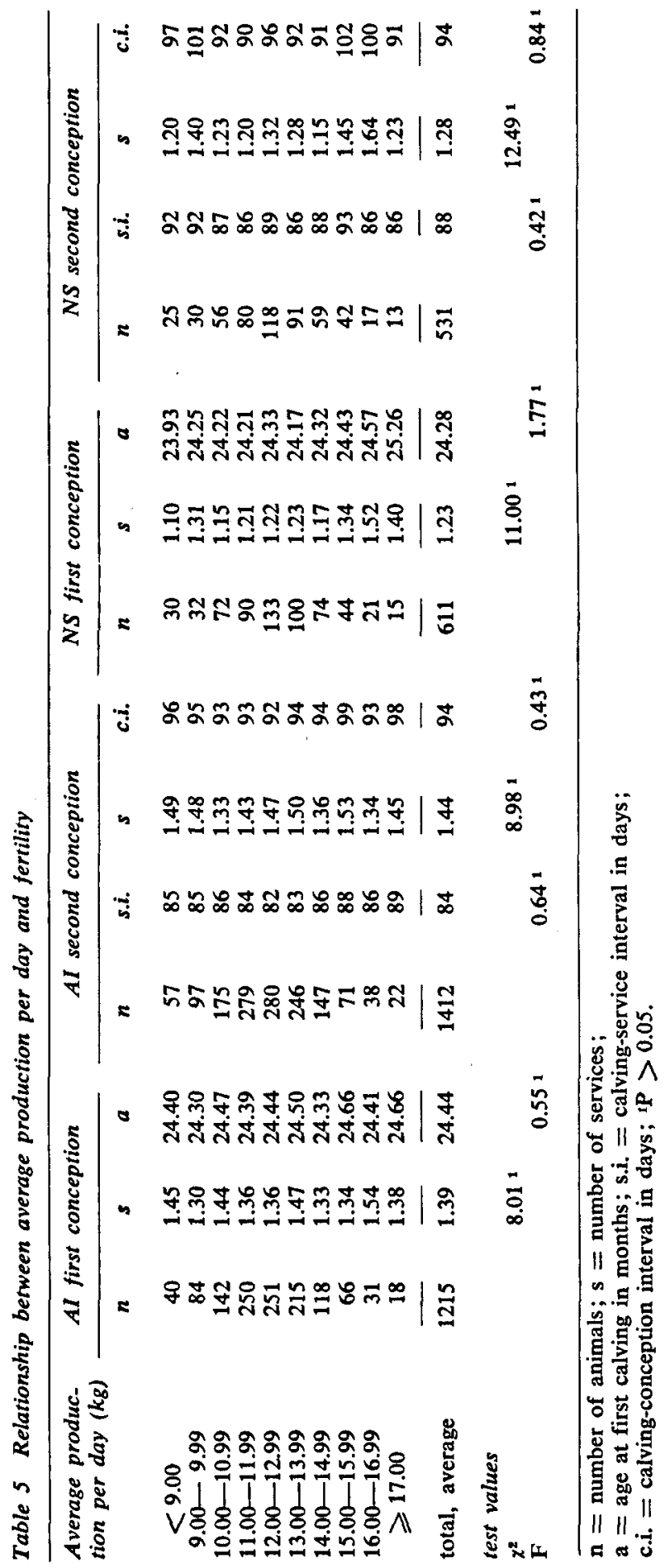


FERTILITY AND MILK PRODUCTION IN DUTCH FRIESIAN CATTLE

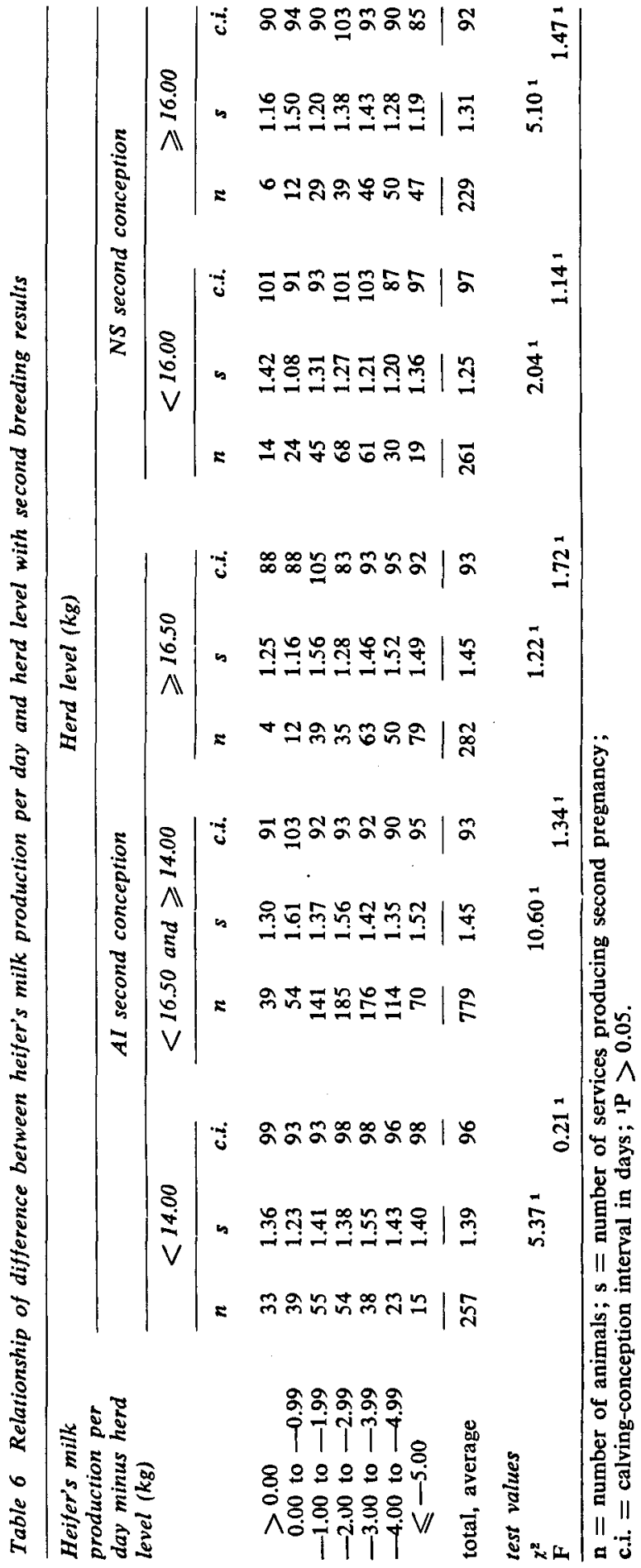

Neth. J. agric. Sci. 18 (1970) 
Table 7 Relationship between herd level and fertility

\begin{tabular}{|c|c|c|c|c|c|c|}
\hline \multirow{2}{*}{$\begin{array}{l}\text { Herd level } \\
(\mathrm{kg})\end{array}$} & \multicolumn{3}{|c|}{ AI heifers } & \multicolumn{3}{|c|}{ NS heifers } \\
\hline & $n$ & $s_{t}$ & $s_{2}$ & $n$ & $s_{t}$ & $s_{2}$ \\
\hline $\begin{array}{c}<14.00 \\
14.00-14.99 \\
15.00-15.99 \\
\geqslant 16.00\end{array}$ & $\begin{array}{l}231 \\
281 \\
302 \\
297\end{array}$ & $\begin{array}{l}1.38 \\
1.30 \\
1.44 \\
1.46\end{array}$ & $\begin{array}{l}1.40 \\
1.46 \\
1.43 \\
1.48\end{array}$ & $\begin{array}{r}52 \\
67 \\
102 \\
198\end{array}$ & $\begin{array}{l}1.26 \\
1.22 \\
1.21 \\
1.25\end{array}$ & $\begin{array}{l}1.17 \\
1.31 \\
1.26 \\
1.31\end{array}$ \\
\hline $\begin{array}{l}\text { total, average } \\
\text { test values }\end{array}$ & 1111 & $\begin{array}{c}1.40 \\
x^{2}=8.45 *\end{array}$ & $\begin{array}{c}1.45 \\
\chi^{2}=1.60^{1}\end{array}$ & 419 & $\begin{array}{c}1.24 \\
x^{2}=0.721\end{array}$ & $\begin{array}{c}1.28 \\
x^{2}=2.80\end{array}$ \\
\hline
\end{tabular}

$\bar{n}=$ number of animals; $s_{1}=$ number of services producing first pregnancy; $s_{2}=$ number of services producing second pregnancy; ${ }^{\mathrm{P}}>0.05 ;{ }^{*} \mathrm{P}<0.05$.

Influence of herd environment on fertility

The calculations concerning the relationship between the herd environment as measured by the production level of the herd and the number of services are shown in Table 7. The test value was only significant for the relationship between the first breeding result and the herd level in the AI group. In this group the heifers from herds with a moderate herd level showed a somewhat better fertility, but in the NS group hardly any difference was found. Although farming intensity may possibly influence fertility to a certain extent, it seems to be of minor importance.

In subsequent calculations the total influence of the herd environment on the average production per day was compared with their influence on fertility. Because the parametric analyses of variance were applied, the numbers of services were not used in the calculations. The material was not divided according to the breeding method. So its systematic influences on the character of fertility used were associated with the farming influences, because the same breeding method was applied in nearly all cases within herds per class of parity.

In the analysis of variance three sources of variance were distinguished: differences

Table 8 Influence of milk recording district and herd environment on average production per day and some fertility characters

\begin{tabular}{lcccc}
\hline $\begin{array}{l}\text { Components } \\
\text { of } \\
\text { variance }\end{array}$ & $\begin{array}{c}\text { Average } \\
\text { production } \\
\text { per day }\end{array}$ & $\begin{array}{c}\text { Age at } \\
\text { first } \\
\text { calving }\end{array}$ & $\begin{array}{c}\text { Calving- } \\
\text { service } \\
\text { interval }\end{array}$ & $\begin{array}{c}\text { Calving- } \\
\text { conception } \\
\text { interval }\end{array}$ \\
$\begin{array}{l}\text { variance between milk recording } \\
\text { districts (\% of total variance) }\end{array}$ & $0.19 * *$ & $0.38 *$ & 0.161 & 0.111 \\
$\begin{array}{l}\text { variance between herds within } \\
\text { districts (\% of total variance) }\end{array}$ & $40.32 * *$ & $16.26 * *$ & $12.48 * *$ & $6.29 *$ \\
rest variance (\% of total variance) & 59.49 & 83.36 & 87.36 & 93.60 \\
\hline
\end{tabular}


between districts of milk recording (d.f. $=7$ ), differences between herds within districts (d.f. $=537)$ and the sources of rest variance (d.f. $=1398)$. The results af the calculations are given in Table 8.

There was only a significant influence of the districts on the age at first calving and the average production per day. With every character the whole complex of factors associated with the districts caused less than $0.40 \%$ of the total variance. This indicated that the investigated material came from a rather uniform region.

The differences between herds had a significant influence on all characters. Herd environment was responsible for about $40 \%$ of the variance in milk production of individual heifers, but was less important for the age at first calving $(16 \%)$, the calving service period $(12 \%)$ and the calving-conception interval $(6 \%)$. This is in agreement with previous results (Tables 1 and 7).

It could be concluded that the total picture of herd environment provides really more indications for the level of milk production of the individual heifer than for its fertility.

Genetic relationship between milk production and fertility

Falconer's equation (1960) below shows how the genetic causes of correlation contribute to the phenotypic correlation: $r_{p}=h_{x} h_{y} r_{A}+e_{x} e_{x} r_{E}$, where:

$\mathbf{x}$ and $\mathbf{y}=$ two characters under consideration;

tp $=$ phenotypic correlation between the two characters $x$ and $y$;

$\mathrm{r}_{\mathrm{A}}=$ additive genetic correlation between $\mathrm{x}$ and $\mathrm{y}$;

$\mathrm{r}_{\mathrm{E}}=$ environmental correlation between $\mathrm{x}$ and $\mathrm{y}$ (including non-additive genetic effects);

he $\quad=$ the heritability, with subscript $x$ and $y$, according to the characters;

$\mathrm{e}^{2}=\left(1-\mathrm{h}^{2}\right)$.

In our material both the additive genetic correlations and the heritability were estimated. For this purpose. AI material with 935 heifers from 35 daughter groups with at least 5 heifers per group distributed over at least 3 herds was used. Thus the estimations were based on half-sib analysis.

As is shown in Table 9, the estimated heritability of the average production per day $\left(h^{2}=0.31\right)$ was much higher than for the fertility characters. A heritability of 0.08 was calculated both for the number of services necessary for first and second pregnancy and for age at first calving. According to the $F$ test for daughter-group effects, the heritability of calving service and the conception were not significant.

The calculated phenotypic and additive genetic correlations are shown in Table 10. None of these values were significant. To test the additive genetic correlation confidence limits were calculated with $P=0.05$ according to the formula of Falconer

Table 9 Heritabilities of average production per day and fertility characters

\begin{tabular}{ll}
\hline Characters & $h^{2}$ \\
Average daily production & $0.31^{* *}$ \\
Number of services for first pregnancy & $0.08^{*}$ \\
Number of services for second pregnancy & $0.08^{*}$ \\
Age at first calving & $0.08 *$ \\
Calving-service interval & 0.021 \\
Calving-cocnception interval & 0.011 \\
\hline
\end{tabular}

${ }^{* *} \mathrm{P}<0.005 ; * \mathrm{P}<0.05 ;{ }^{1 \mathrm{P}}>0.05$.

Neth. J. agric. Sci. 18 (1970) 
Table 10 Phenotypic and additive genetic correlations between average production per day and the characters of fertility

\begin{tabular}{lcr}
\hline & $\begin{array}{c}\text { Phenotypic } \\
\text { correlation }\end{array}$ & $\begin{array}{c}\text { Additive genetic } \\
\text { correlation } \pm 1.96 S\end{array}$ \\
$\begin{array}{l}\text { Average production per day } \times \begin{array}{l}\text { number of services } \\
\text { for first pregnancy }\end{array} \\
\text { Average production per day } \times \begin{array}{l}\text { number of services } \\
\text { for second pregnancy }\end{array}\end{array}$ & +0.031 & $+0.03 \pm 0.67$ \\
$\begin{array}{l}\text { Average production per day } \times \text { age at first calving } \\
\begin{array}{l}\text { Average production per day } \times \text { calving-service interval } \\
\text { Average production per day } \times \text { calving-conception }\end{array}\end{array}$ & +0.031 & $+0.39 \pm 0.59$ \\
interval & +0.041 & $-0.30 \pm 0.67$ \\
\end{tabular}

PP $>0.05$.

(1960). The intervals of two correlations exceeded the range of possible values, and this is certainly caused by normal estimation errors. The results of these calculations confirm previous results (Table 5 and 6) and are in agreement with results of Weseloh (1968).

\section{Discussion}

In this investigation field data were collected on milk production and fertility in a district with a good production level by Dutch standards. Of course field data may be slightly less suitable owing to selection influences. In the present study the less productive heifers culled during lactation has not been included in our material, nor have heifers which failed to breed. Although more fundamental research on the physiology of milk production and fertility can give valuable results, the relationship between these two factors in everyday farming conditions can only be studied with the aid of sufficient field data.

The analyses have corroborated the conclusion of most authors that there is no evidence for a negative correlation between milk production and fertility. So it was impossible to detect stress effect of high milk production in first lactation on fertility. It may be stated that in the range of farming conditions studied there is ample scope for increase in milk production by breeding and better feeding management, without the risk of a harmful effect on fertility.

\section{References}

Boyd, H. \& Reed, H. C. B., 1961. Investigations into the incidence and causes of infertility in dairy cattle - influence of some management factors affecting the semen and insemination conditions. Brit. vet. J. 117 : 74-86.

Boyd, L. J., Seath, D. M. \& Olds, D., 1954. Relationship between level of milk production and breeding efficiency in dairy cattle. J. Anim. Sci. 13: 89-93.

Currie, E. J., 1956. The influence of milk yield on fertility in dairy cattle. J. Dairy Res. 32: 301-304.

Damm, H. J., 1965. Beziehungen zwischen Milchleistung und Fruchtbarkeit beim Rind (Untersuchun. gen in Grünland betrieben). Thesis, Hannover.

Dannenberg, K., 1967. Ist die Konzeptionsbereitschaft beim Rind leistungsabhängig? Thesis, Göttingen.

Falconer, D. S., 1960. Introduction to quantitative Genetics. Oliver and Boyd, Edinburgh/London. 
Gaines, W. L., 1927. Milk yield in relation to recurrence of conception. J. Dairy. Sci. 10: 117-125. Jonge, $H$. de, 1963. Inleiding tot de medische statistiek. Nederlands Instituut voor Praeventieve Geneeskunde, Leiden. Afd. Statistiek.

Lampo, P., Vanschoubroek, F. \& Willems, A., 1963. De invloed van de kalvingsmaand, de melkproduktie, het vet-, eiwit- en het laktosegehalte op de duur van de tussendrachtperiode bij OostVlaamse stamboekvaarzen. Vlaams Diergeneesk. Tijdschr. 32: 217-231.

Smith, J. W. and Legates, J. E., 1962. Relation of days open and days dry to lactation milk and fat yields. J. Dairy Sci. 45: 1192-1198.

Touchberry, R. W., Rottenstein, K. \& Anderson, H., 1959. Associations between service interval, interval from first service to conception, number of services per conception, and level of butterfat production. J. Dairy Sci. 42: 1157-1170.

Weseloh, E., 1968. Zusammenhänge zwischen Milchleistung, Fruchtbarkeit und Lebensdauer beim Rind, untersucht an Deutschen Schwarzbunten der Herdbuchgesellschaft Osnabrück. Thesis, Göttingen. 